\title{
DISCURSO SOBRE O MÉTODO POÉTICO: O MEDALHÃO ENIGMÁTICO NO TAPETE
}

\section{FLÁVIO RICARDO VASSOLER}

Universidade de São Paulo

São Paulo, São Paulo, Brasil

Resumo: O artigo desenvolve um diálogo estrutural entre os contos "The figure in the carpet" [A figura no tapete] (1896), de Henry James, e "Teoria do medalhão" (1881), de Machado de Assis, de modo a demonstrar como o movimento da forma estabelece, em ambas as narrativas, sentidos polissêmicos que dão vazão a conteúdos volúveis e contraditórios.

Palavras-chave: Enigma formal; contradição; conteúdo volúvel; ironia; polissemia; Machado de Assis; Henry James.

\section{DISCOURSE ON THE POETIC METHOD: THE PUZZLING MEDALLION IN THE CARPET}

Abstract: The article develops a structural dialogue between the short stories "The figure in the carpet" (1896), by Henry James, and "Theory of medallion" (1891), by Machado de Assis, in order to demonstrate how the movement of form establishes, in both narratives, polysemic meanings which enable fickle and contradictory contents.

Keywords: Formal puzzle; contradiction; fickle content; irony; polysemy; Machado de Assis; Henry James.

\section{Breve panorama da trajetória analítica}

\section{A} trajetória desta análise começará, in media res, por perseguir os rastros deixados pelo enigma que estrutura "The figure in the carpet" [A figura no tapete], de Henry James. Desvelaremos a tessitura do tapete, os fios 
que entretecem o conteúdo enigmático precipitado pela forma poética. Os resultados da análise da poética estruturalmente enigmática de James nos conduzirão pela "Teoria do medalhão", de Machado de Assis, para compreendermos a lógica irônica e contraditória de movimentação da forma, ao invés de estabelecermos uma leitura unívoca para o conteúdo do conto. Nesse sentido, a análise da narrativa de James despontará como o pressuposto fundamental para a leitura de Machado de Assis e preparará a forja para o medalhão da elite brasileira oitocentista, de modo que o maquiavelismo do pai de Janjão nos conduza ao movimento estrutural da ironia que, a meu ver, mimetiza a dinâmica formal do enigma enredado pela figura no tapete. ${ }^{1}$

\section{2. "A figura no tapete": Discurso sobre o método poético}

\subsection{O conteúdo do enigma como o movimento da forma}

O narrador de "A figura no tapete", de Henry James, desvela sua dialogia desde a apresentação mais tenra: "I had done a few things and earned a few pence - I had perhaps even had time to begin to think I was finer than was perceived by the patronising". ${ }^{2}$ [Eu fizera algumas coisas e ganhara algum dinheiro - quiçá eu tenha tido até mesmo tempo para começar a pensar que tinha mais valor do que meus patrões consideravam. ${ }^{3}$ ] Eis a tensão sempre rediviva entre aquilo que se realiza e o reconhecimento que (não) se obtém. Se pensarmos que o narrador, cujo nome permanece tão incógnito quanto o enigma da figura, tomará para si o dilema de Hugh Vereker, o pai do nômeno literário de James, descobrimos uma lógica subliminar em meio a uma introdução supostamente aleatória. Senão, vejamos: trata-se de um descompasso necessário entre o reconhecimento do outro e a percepção que o eu faz de si mesmo. Se deixarmos de pensar em termos entitários, ou seja, se deixarmos de separar o eu do tu, poderemos dizer

\footnotetext{
${ }^{1}$ A análise desenvolvida neste artigo embasou-se em estudos seminais sobre: (i) "Teoria do medalhão": VILLAÇA, Janjão e Maquiavel: a Teoria do medalhão; (ii) as interfaces envolvendo Henry James e Machado de Assis: PARREIRA, Realidade possível: dilemas da ficção em Henry James e Machado de Assis. "The figure in the carpet" [A figura no tapete] está disponível em português a partir da seguinte edição: JAMES, O desenho no tapete. In: A morte do leão: histórias de artistas e escritores. Tradução de Paulo Henriques Britto. São Paulo: Companhia das Letras, 1993, p. 144-180.

${ }^{2}$ JAMES, The figure in the carpet (E-book), p. 5.

${ }^{3}$ As traduções livres, entre colchetes, foram feitas por mim.
}

Machado de Assis Linha, São Paulo, v. 8, n. 15, p. 55-75, junho 2015

Universidade de São Paulo - Faculdade de Filosofia, Letras e Ciências Humanas 
que o narrador, desde o início, postula a relação eu-tu, vale dizer, o nós, como uma primeira chave etérea para a apreensão da figura no tapete.

O narrador, a despeito de sua independência solvente - "I had done a few things and earned a few pence" ${ }^{\prime 4}$ [Eu fizera algumas coisas e ganhara algum dinheiro] -, não é lido pelas instâncias superiores como deveria - "I was finer than was perceived by the patronising" 5 [Eu tinha mais valor do que meus patrões consideravam]. Tomar a descoberta da figura no tapete para si, nesse sentido, faria com que o reconhecimento do outro viesse ao encontro do juízo que o eu faz sobre si mesmo desde o início do conto. E mais: o plano mais epidérmico do conteúdo nos deixa entrever um descompasso estrutural entre os juízos recíprocos. Ainda que a figura no tapete possa ser descoberta, quem pode garantir a coincidência entre os juízos, uma vez que o eu não se faz repleto sem o tu? O enigma pressupõe, assim, não apenas um único leitor, mas uma teia de leitores. Tal teia, por sua vez, pressupõe a diferença e prenuncia o descompasso. Veremos, então, que o dilema do grande escritor Hugh Vereker se refere à tentativa de erigir uma estátua para a figura no tapete, ao passo que ela parece pedir justamente o fluido contínuo da sucessão de camadas leitoras. Uma lógica do movimento contraditório.

O narrador é um crítico literário que escreve para jornais. Hugh Vereker é o escritor cujo dilema tentará ser elucidado pelo mediador inequívoco da estória. $\mathrm{O}$ conto de James tem seus pontos máximos de tensão nos diálogos entre o escritor e o crítico. Se não nos esquecermos de que não há uma instância exterior e onisciente a compilar os supostos fatos, uma vez que o narrador participa da narrativa, perceberemos mais uma deformação estrutural da proposição da verdade enigmática. ${ }^{6}$ Afinal, "all I pretend is that the author doesn't see"7 [eu só faço fingir que o autor não vê], diz Vereker quando interpelado por nosso narrador inominado.

\footnotetext{
${ }^{4}$ JAMES, cit., p. 5.

${ }^{5}$ Ibidem.

${ }^{6}$ Se utilizarmos a mesma lógica para a apreensão do dilema de Dom Casmurro - Capitu, adúltera ou não? -, poderemos nos posicionar de modo algo diferente. Ao invés de tentarmos solucionar o dilema cabalmente, perceberemos que não é a síntese o mecanismo que enforma a narrativa e lhe dá motricidade, mas o entrechoque entre tese e antítese. "Quando os críticos discordam entre si, o artista concorda consigo mesmo". WILDE, Aforismos ou mensagens eternas, p. 53. Assim, ao invés de descobrirmos o conteúdo (inatingível) do enigma, poderemos predizer que novos dilemas serão enredados pela forma contraditória que dá sustentação a tal poética.

7 JAMES, cit., p. 11.
}

Machado de Assis Linha, São Paulo, v. 8, n. 15, p. 55-75, junho 2015

Universidade de São Paulo - Faculdade de Filosofia, Letras e Ciências Humanas 
"What then may your 'little point' happen to be?"8 [Qual seria, então, o seu "pequeno ponto"?] - pergunta nosso foco narrativo. A resposta opaca de Vereker enuncia menos o conteúdo de sua verdade e mais a forma em meio à qual e por meio da qual ele se movimenta:

By my little point I mean - what should I call it? - the particular thing I've written my books most FOR. Isn't there for every writer a particular thing of that sort, the thing that most makes him apply himself, the thing without effort to achieve which he wouldn't write at all, the very passion of his passion, the part of the business in which, for him, the flame of art burns most intensely? Well, it's THAT.'

[Meu pequeno ponto seria - como eu deveria chamá-lo? - o MOTE particular que mais me levou a escrever meus livros. Para todo escritor, não há algo assim particular, a coisa que mais lhe traz vigor, algo que, sem cujo esforço de expressão, ele não escreveria de forma alguma, a verdadeira paixão de sua paixão, a parte do negócio na qual, para o escritor, a chama de sua arte arde mais intensamente? Bem, é ISSO.]

Se, ao invés de nos obsedarmos com a ardência do dilema, tentarmos descobrir o que provoca o ardor, ou melhor, como ele é suscitado, poderemos chegar à lógica de estruturação do mistério, vale dizer, será possível descobrir o paradoxo que esclarece a forma pela qual o mistério vem à tona, sem que possamos dizer no que o mistério propriamente dito consiste.

O escritor, salvo engano, busca de fato o mote de sua expressão, persegue incansavelmente o sentido do que tem a dizer praticamente como um destino manifesto. No entanto, não se trata de um modo de expressão ao léu. O escritor cria segundo uma sintaxe, segundo uma forma sobre a qual possui mais ou menos consciência. Quando menos percebe, o sentido que o leva a escrever já se funde à própria forma pela qual o faz. O sentido da escrita torna-se a forma do conteúdo. O que há para ser dito já não se distingue do próprio dizer, de sua forma de expressão. É assim que, a meu ver, pode ser interpretada a "passion of his passion"10 [paixão de sua paixão] à qual Vereker faz referência. A metalinguagem não me parece nada gratuita. Geralmente, o artista como que

${ }^{8}$ Idem, p. 13.

${ }^{9}$ Idem, p. 14.

${ }^{10}$ Ibidem.

Machado de Assis Linha, São Paulo, v. 8, n. 15, p. 55-75, junho 2015

Universidade de São Paulo - Faculdade de Filosofia, Letras e Ciências Humanas 
aceita - ou é coagido a aceitar, no mínimo por prudência política - a tradicional divisão do trabalho literário entre a criação e a crítica. ${ }^{11}$ No conto em questão, Vereker desvela ao narrador a dinâmica de seu dilema, a forma pela qual o enigma dilacera o autor, mas, como a reiterar a tradição que separa o criador da crítica, o escritor não consegue trazer o dilema à tona, não consegue lhe dar um conteúdo cabal para além da moldura própria à forma. Logo entendemos, então, que o narrador toma a resolução do dilema como um desafio pessoal que, desde o início do conto, já havia sido prenunciado como um ímpeto identitário central. Nosso foco narrativo, o mediador inequívoco da verdade velada, toma para si o fardo de alinhavar a figura no tapete, de modo a torná-la inteligível.

I ought to leave that to somebody else to say; but that nobody does say it is precisely what we're talking about. It stretches, this little trick of mine, from book to book, and everything else, comparatively, plays over the surface of it. The order, the form, the texture of my books will perhaps some day constitute for the initiated a complete representation of it. So it's naturally the thing for the critic to look for. It strikes me [...] even as the thing for the critic to find. ${ }^{12}$

[Eu tenho que deixar isso para outra pessoa descobrir; mas que ninguém de fato o descubra é precisamente do que estamos falando. Esse meu pequeno truque se prolonga de livro a livro, e tudo o mais, comparativamente, apenas desliza pela superfície do truque. Um dia, talvez, a ordem, a forma, a textura dos meus livros constituirão para os iniciados uma representação completa do truque. Assim, naturalmente, trata-se daquilo que os críticos devem buscar. Ele me toma [...] até mesmo como a coisa que os críticos devem descobrir.]

Se "everything else [...] plays over the surface of $i^{\prime \prime 13}$ [tudo o mais [...] desliza pela superfície do truque], parece-me propício dizer que a forma do enigma lembra uma esfera, no encalço da qual os críticos só fazem resvalar a

\footnotetext{
${ }^{11}$ Henry James, ao longo de sua carreira, sempre criou ao mesmo tempo em que escrevia profícuas críticas literárias. Assim, em "A figura no tapete", a instância autoral se biparte ficcionalmente nas figuras do narrador e de Hugh Vereker para compor algo que James sempre vivenciou de maneira sintética em sua atividade de escritor/crítico literário. Para mais detalhes, conferir: JAMES, $A$ arte do romance: antologia de prefácios.

12 JAMES, The figure in the carpet (E-book), p. 14, grifos meus.

13 Ibidem.
} 
superfície esguia e sem firme apoio. Sendo assim, Hugh Vereker, ao expor o movimento de sua chama interior, contribui para a descoberta na mesma medida em que a torna mais obscura. Afinal de contas, se a figura no tapete fosse desvelada e revelada de uma vez por todas, a obra de Hugh Vereker não resistiria ao transcurso do tempo e não se transformaria em um legado - a própria tarefa do narrador se esgotaria em seu ofício de arqueologia literária, uma vez que o nômeno literário do autor já fora desvendado. Por outro lado, se a revelação pressupusesse sempre a sombra projetada pelo véu, o papel de Vereker se tornaria estruturalmente ambíguo e dialógico.

Se considerarmos Vereker um autor astuto que fomenta a dúvida para prolongar a vivacidade de sua obra entre a crítica, ainda assim estaremos diante do caráter relacional entre a instância de criação e as instâncias de recepção. No entanto, se aceitarmos que Vereker de fato não consegue expressar o sentido de sua atividade literária em uma epígrafe cabal, o outro é pressuposto ainda uma vez. "It's naturally the thing for the critic to look for. It strikes me even as the thing for the critic to find". ${ }^{14}$ [Assim, naturalmente, trata-se daquilo que os críticos devem buscar. Ele me toma até mesmo como a coisa que os críticos devem descobrir.] Gera-se, assim, uma circularidade para as recepções supostamente antípodas do conto de James, um padrão pressuposto pela forma do enigma. A alternativa ou isso, ou aquilo não dá conta do movimento poético precisamente por aceitar o mesmo dilema no qual o narrador mergulha sem mais. Astuto ou trágico, hábil ou parcialmente consciente, Vereker, por intermédio do narrador desafiado, lança um dilema para que o leitor reverbere a impossibilidade de descoberta em suas leituras potencialmente sucessivas. A cada leitura, o leitor busca um ângulo diverso para apreender a figura no tapete. Ele talvez sinta que perdeu algo, então é preciso percorrer a estória de novo e revirar o tapete persa ainda uma vez. O leitor, ávido como o narrador, mal se dá conta de que a esfera, em sua sinuosidade, não apresenta ângulo algum. Assim, já não se trata do decifra-me ou devoro-te, mas do decifra-me enquanto te devoro. Querer descobrir o enigma pelas sucessivas mediações de Vereker e do narrador profundamente parcial implica reter o movimento poético da esfera. Como retaliação, a figura no tapete mostra-se ainda mais enigmática em sua sempre iminente (in)definição. Trata-se de algo tão fugidio quanto o tempo para Santo

${ }^{14}$ Ibidem.

Machado de Assis Linha, São Paulo, v. 8, n. 15, p. 55-75, junho 2015

Universidade de São Paulo - Faculdade de Filosofia, Letras e Ciências Humanas 
Agostinho: ${ }^{15}$ o teólogo dizia que, se não lhe fosse perguntado, bem saberia dizer o que era o tempo, mas, no momento em que fosse interpelado, o tempo lhe escaparia entre os dedos como os grãos de areia através do delgado pescoço da ampulheta. Talvez valha para a figura no tapete um aforismo que arregimente o tempo: o tempo nos transforma, mas permanece idêntico a si mesmo. A figura no tapete transforma os leitores e transforma a própria relação com a leitura, mas, para permanecer idêntica a si mesma, a figura precisa se transformar em um receptáculo, algo como uma forma vazia que, historicamente, recebe diversos conteúdos a depender dos conflitos que sua estrutura possa animar.

Podemos pressupor que Machado de Assis e, claro, o próprio Henry James se identificariam profundamente com a definição irresoluta de Hugh Vereker. Se nos lembrarmos das acirradas disputas pela fortuna crítica do escritor brasileiro, diremos que os autores souberam tornar polissêmicas suas obras, de modo que a palavra final da crítica fosse apenas o término temporal vinculado a uma nova sequência de leituras. Não a linearidade, mas a contradição. Não o acabamento, mas a incompletude. Se Vereker diz que sua verdade transpassa toda a sua obra, podemos dizer que a figura não deve ser separada do próprio tapete; a obra completa contém, como uma galeria a ser escavada, a verdade do autor. A máscara também revela os contornos do rosto. Enquanto o crítico aceitar o dilema do artista sem atentar para a deformação subjacente à voz poética, a esfera continuará girando e seu cerne vazio e opaco não será alcançado. Porém, no momento em que o movimento da forma receber a luz da crítica, a esfera será capturada em seu próprio transcurso. Não tentaremos pará-la, a narrativa pressupõe o movimento, mas tentaremos seguir e perseguir os trilhos sobre os quais a esfera poética se movimenta. A figura não precisará ser removida de seu tapete. É nesse sentido que James erige as bases fluidas sobre as quais e com as quais caminharemos para apreender a volubilidade do pai de Janjão, em "Teoria do medalhão".

\subsection{O movimento irônico da forma como prolongamento do conteúdo enigmático}

${ }^{15}$ SANTO AGOSTINHO, Confissões. 
Por ora, no entanto, não sejamos afoitos como o narrador-detetive de James e continuemos a perseguir os rastros das pegadas sobre o tapete.

The thing's as concrete there as a bird in a cage, a bait on a hook, a piece of cheese in a mousetrap. It's stuck into every volume as your foot is stuck into your shoe. It governs every line, it chooses every word, it dots every $i$, it places every comma. ${ }^{16}$

[A coisa é tão concreta quanto um pássaro na gaiola, uma isca no anzol, um pedaço de queijo em uma ratoeira. Ela está em cada livro como seu pé está dentro do sapato. Ela governa cada linha, ela escolhe cada palavra, ela põe todos os pingos nos is, ela pontua cada vírgula.]

Vereker, em seu jogo literário de claro e escuro, lança forma e conteúdo em um bailado tenso e contraditório. Os pés costumam estar dentro dos sapatos, vale dizer, o conteúdo está contido no invólucro. Se a relação de posse não ficou tão clara, que dizer da isca rasgada pelo anzol? Mas, além da posse, há a captura sempre iminente - o corolário das leituras sucessivas que aceitam a forma do dilema sem questioná-la: como não pensar que o queijo oferecido pela ratoeira prenuncia o pássaro que se choca contra as grades da gaiola?

O pássaro e a gaiola; a isca e o anzol; o queijo e a ratoeira; os pés e os sapatos: figuras recíprocas, figuras que se pressupõem, mas que não podem ser confundidas umas com as outras. O pássaro não é idêntico à gaiola, ainda que a ideologia mais conservadora sempre diga que a isca pressupõe o anzol. Ao perseguirmos a lógica estrutural do dilema, chegamos a pares contraditórios que insinuam a enformação que aparta o conteúdo da forma. Aquele que persegue o pássaro acaba se chocando contra as grades da gaiola. A isca e o queijo já sabem o que os espera. Mas se continuarmos com nossos entrechoques poéticos, chegaremos a uma frase algo autoral, uma chave hermenêutica que diz mais sobre a lógica poética do que sobre o conteúdo volúvel: "It governs every line, it chooses every word, it dots every $i$, it places every comma" ${ }^{17}$ [Ela governa cada linha, ela escolhe cada palavra, ela põe todos os pingos nos is, ela pontua cada vírgula.] Os governantes pressupõem não apenas os governados, mas também o governo propriamente dito. Havia uma estrutura governamental previamente democrática para que votássemos em Lula e para que o ex-metalúrgico pudesse

${ }^{16}$ JAMES, The figure in the carpet (E-book), p. 17.

17 Ibidem.

Machado de Assis Linha, São Paulo, v. 8, n. 15, p. 55-75, junho 2015

Universidade de São Paulo - Faculdade de Filosofia, Letras e Ciências Humanas 
ser presidente. Assim, o princípio anterior à figura no tapete governa a sua constituição; um princípio sintático ao extremo, a crermos, não sem desconfiança, nas palavras do narrador. Um princípio que lança mão da narrativa na mesma medida em que nela não se esgota. Algo que coincide com o texto e seus elementos, mas que deles também se diferencia.

For himself [Vereker], beyond doubt, the thing we were all so blank about was vividly there. It was something, I guessed, in the primal plan, something like a complex figure in a Persian carpet. He highly opposed of this image when I used it, and he used another himself: 'It's the very string', he said, 'that my pearls are strung on!'18

[Para ele (Vereker), sem dúvida, a coisa que nos parecia tão opaca estava vividamente presente. Era algo, assim eu pensei, pertencente ao plano original, algo como uma complexa figura em um tapete persa. Ele se opôs fortemente a essa imagem quando eu a empreguei, então ele próprio empregou uma outra: "Trata-se do próprio cordão", ele disse, "que reúne minhas pérolas em um colar!"]

Curiosa oposição: Vereker, segundo o narrador, rejeitou frontalmente a metáfora erigida pelo próprio narrador, mas "The figure in the carpet" [A figura no tapete], com a aquiescência autoral de James, tornou-se o título do conto em questão. O narrador caminha em círculos, mas seus soslaios tangenciam a lógica de movimentação poética, até que Hugh Vereker, por sua vez desafiado, lança mão de uma metáfora fundamental para nossa análise: "It's the very string that my pearls are strung on!"19 [Trata-se do próprio cordão que reúne minhas pérolas em um colar!]. Se o dilema artístico-existencial de Vereker pode ser comparado ao cordão que conecta suas pérolas, chegamos a uma dualidade relacional que sulca, enfim, uma clivagem nítida entre a forma do enigma e os diversos conteúdos que ele pode sustentar. As pérolas, por mais cuidadoso que seja o ourives, tendem a se distinguir umas das outras, ainda que de modo ínfimo. Já o cordão se transforma e permanece idêntico a si mesmo. Seu comprimento se mantém, mas sua forma volúvel se adapta para receber as mais diversas conformações da sequência de pérolas. Sendo assim, aquele que sonda as pérolas sem entrever o caráter relacional que as conecta está fadado a

${ }^{18}$ Idem, p. 23, grifos meus.

${ }^{19}$ Ibidem. 
encontrar as grades da gaiola e o gato sequioso junto à ratoeira. $\mathrm{O}$ dilema não se resolve, mas a sintaxe de sua expressão gera a forma por meio da qual diferentes sentidos artísticos podem vir à tona. Reciprocamente, o cordão não pode ser indiferente às distintas conformações das pérolas. A cada tentativa de enquadramento do conteúdo proposta pelo narrador, o cordão artísticoexistencial de Vereker se contrai e se distende para, em seu movimento, compreender toda uma miríade de possibilidades contraditórias entre si. O enigma se prolonga na medida em que permanece enigmático. Nesse sentido, o conto pode compreender duas metáforas globais, a depender do plano de apreciação que estejamos a analisar. Uma estória de busca, o corredor polonês do detetive, se estivermos ao lado das sondagens inglórias do narrador, se nos ativermos ao conteúdo. Porém, ao acompanharmos o movimento da forma esférica, a estória de detetive transforma-se em um discurso sobre o método poético, isto é, um transcurso metalinguístico cuja hermenêutica, a meu ver, requer não a proposição de um conteúdo unívoco para o dilema artísticoexistencial de Vereker, mas a percepção de que o enigma do escritor se confunde com a própria trajetória de sua obra, com a própria forma pela qual os mais diversos conteúdos transformam-se em narrativas. Alcançar de uma vez por todas o cerne artístico implicaria tornar monocromática a paleta que compreende a polissemia das cores. Diferentes respostas postulam a primazia do enigma, mas talvez se trate de uma pergunta que se alimenta de si mesma, o movimento da dúvida que só se resolve na medida em que continua a hesitar sem solução.

Quando Vereker morre, o narrador se desespera. Ele acredita que o editor conheça a resposta, que a viúva de Vereker sem dúvida deve conhecer a solução do enigma. Mas, como a forma esférica já prenunciava, o dilema só finda, ficcional e temporariamente, com o ponto final. Não há resolução, mas também não há um término. A máxima latina de Virgílio, mencionada ao longo dos diálogos, se confundirá com o sentido desta análise cinética que faz a figura caminhar sobre o tapete: vera incessu patuit dea, vale dizer, manifestou-se verdadeira deusa pelo modo de caminhar. A deusa não se mostra divina, então, pelo conteúdo do que diz, mas pelo movimento poético que executa. Não a palavra, mas o que lhe dá vazão, seu sentido dinâmico de expressão. Em dado momento da estória, o narrador nos revela que seu irmão estuda na Alemanha. Trata-se, supostamente, de uma colocação ao léu, de um dado tão aleatório 
quanto um pedestre anônimo e desavisado pela avenida Paulista. No entanto, a figura no tapete, em seu dinamismo, refaz a mesma volta do parafuso que torna causais e referenciais mesmo os elementos mais aparentemente desconexos da narrativa.

Analisemos, nesse sentido, o nome do escritor/narrador-personagem: Hugh Vereker. Hugh, "from [...] hug, meaning 'heart, mind, spirit'"20 [a partir de hug, que significa 'coração, mente, espírito']. Eis ainda uma vez o caráter visceral do dilema de nosso autor, o cerne de seu coração espirituoso encarnado em seu nome. E, como se não bastasse, Hugh nos remete a huge [enorme], tamanha a imensidão do enigma, tamanha a ironia que desvela o local da armadilha no preciso momento em que minha perna fica presa sem solução. A confiança plácida na mediação do narrador escamoteia a deformação por que passa a estória a reboque da ironia sub-reptícia. A deformação não se relaciona com a instância narrativa dúbia e parcial como um mero predicado. O narrador sujeitase à dubiedade por conta da própria deformação. Trata-se do caráter estrutural da ironia, irredutível a qualquer zombaria conteudística. Não deixa de ser irônica a procura de um conteúdo específico e cabal que dê conta do dilema. Mas a ironia transcende o fato contingente para se transformar no mecanismo poético que confere motricidade à narrativa. Irônico, sobretudo, é o próprio dilema, uma forma intensa e autofágica que acaba por subsumir todos os conteúdos que se pretendam conquistadores, inclusive a voz do autor, que, em face de seu próprio dilema, também se torna um leitor. Um leitor privilegiado, mas, ainda assim, um leitor.

Mas o grande Hugh não poderia passar sem um sobrenome à altura. Para interpretá-lo, convoquemos o irmão do narrador, cujos estudos germânicos nos serão muito úteis. Vereker, por eufonia, lembra o substantivo Verkehr, que quer dizer "1. trânsito, tráfego, circulação. 2. relação" ${ }^{21} \mathrm{O}$ enigma sempre redivivo já não nos surpreende mais em seu caráter inequivocamente irresoluto. $O$ enigma de Vereker transita pelas relações entre os vários conteúdos que tentam capturálo e a forma esguia e volúvel que prolonga o mistério na medida em que com ele se confunde.

20 BEHIND the Name: The Etymology and History of First Names. Disponivel em: http://www.behindthename.com/name/hugh.

${ }^{21}$ KELLER, Dicionário Michaelis da língua alemã, p. 293, grifos meus. 
A reboque da contradição estrutural que procura desvelar a tessitura da figura no tapete em correlação com seus conteúdos antitéticos, analisemos a partir de agora a lógica sub-reptícia que pode ter cunhado a "Teoria do medalhão" como um sermão paterno e maquiavélico de bem viver, uma apologia ao real que se entrelaça de modo irônico, incestuoso e enigmático com a crítica radical ao existente.

\section{A forja do medalhão machadiano}

\subsection{O enigma da ironia de Machado de Assis: crítica ou apologia?}

Janjão, nascido a 5 de agosto de 1854, completa 21 anos, antiga idade para as maioridades civil e penal. Chega o momento de o pai cônscio traçar um panorama das possibilidades que se descortinam para o filho. O futuro parece promissor, mas o diagnóstico das estratégias e percalços deve ser objetivo, a fim de que Janjão possa tornar-se um autêntico medalhão. Assim, o pai, aspirante outrora frustrado, pode aplacar o próprio ressentimento, pois "qualquer que seja a profissão da tua escolha, o meu desejo é que te faças grande e ilustre, ou pelo menos notável, que te levantes acima da obscuridade comum". ${ }^{22}$ Para tanto, é preciso que a vida ganhe contornos nítidos. O diagnóstico do pai de Janjão atribui laivos praticamente metafísicos ao crivo da sociedade; a desigualdade e a competitividade sociais tornam-se um destino manifesto.

A vida, Janjão, é uma enorme loteria; os prêmios são poucos, os malogrados inúmeros, e com os suspiros de uma geração é que se amassam as esperanças de outra. Isto é a vida; não há planger, nem imprecar, mas aceitar as cousas integralmente, com seus ônus e percalços, glórias e desdouros, e ir por diante. ${ }^{23}$

Com tais avaliações categóricas, o pai de Janjão, para sempre inominado como o narrador de James, parece ter afastado da "Teoria do medalhão" a poética contraditória de "A figura no tapete". O conteúdo parece unívoco, o

${ }^{22}$ ASSIS, Teoria do medalhão, p. 288.

${ }^{23}$ Idem, p. 289. 
conselho paterno procura separar o joio do trigo, para que Janjão saiba discernir entre o cerne (supostamente) metafísico e imutável da vivência social e as possibilidades exíguas que se abrem para todo aquele que consegue percorrer o corredor polonês, ainda que as cicatrizes do trajeto lhe sejam indeléveis. "Com os suspiros de uma geração é que se amassam as esperanças de outra." ${ }^{24}$ Esta sentença cruel traz em seu bojo uma tensão que inicia o processo machadiano de deformação. Senão, vejamos: a geração do pai antecede a geração do filho. Os suspiros esperançosos e frustrados da geração prévia, devidamente ressentidos, esmagam as esperanças da geração posterior. Os conselhos do pai de Janjão, assim, desvelam uma ambiguidade estrutural desde o plano do conteúdo mais epidérmico. Não negamos que o pai queira preparar o filho para as agruras do front social. A preocupação se faz presente, pois, do contrário, não haveria qualquer necessidade de se estabelecer um diálogo. Pai e filho seriam completamente indiferentes um para o outro. No entanto, Machado imiscui os sentimentos, entrevê a contiguidade entre os contrários. A afeição dá a mão ao rancor, a projeção da esperança caminha de braços dados com o desafio. Será mesmo que o filho vai conseguir? O pai não o fez, porque não teve tais indicações. Janjão, congratulado, não poderá usar a desculpa do pai. O ônus da eventual derrota lhe cairá inteiramente sobre os ombros. "Isto é a vida; não há planger, nem imprecar, mas aceitar as cousas integralmente, com seus ônus e percalços, glórias e desdouros, e ir por diante." ${ }^{25}$ Um pai afetuoso poderia ter dito: Isto é a vida lá fora. Aqui dentro, o aprendizado é diverso. Somos pai e filho, somos amigos. Mas, em Machado de Assis, a univocidade de sentido jamais caminha de modo altivo. O pai traz a guerra de todos contra todos para a própria relação fraternal. Por outro lado, não se pode dizer que ele não esteja se preocupando. Afinal, as admoestações de fato ocorrem.

Se a vida é esse vale de lágrimas e misérias, é preciso estar ao lado dos afortunados. É preciso ser sagaz para apreender o movimento da caprichosa deusa Fortuna. Ir por diante, assim, pressupõe a aceitação incondicional das injustiças - e, eventualmente, a sua reprodução, sempre que for preciso, pois isto é a vida. Aceitar as coisas integralmente implica lançar mão dos mais diversos meios para obter o bilhete premiado. A formação, papel precípuo do pai, confunde-se a todo instante com a deformação. Daí a pergunta que começa a

${ }^{24}$ Ibidem.

${ }^{25}$ Ibidem.

Machado de Assis Linha, São Paulo, v. 8, n. 15, p. 55-75, junho 2015

Universidade de São Paulo - Faculdade de Filosofia, Letras e Ciências Humanas 
despontar sob a voz conselheira do pai: haveria uma estrutura formal que estaria a modular o sentido do diálogo? "The figure in the carpet" [A figura no tapete] e o enigma de Hugh Vereker sugerem que sim.

- [...] Assim como é de boa economia guardar um pão para a velhice, assim também é de boa prática social acautelar um ofício para a hipótese de que os outros falhem, ou não indenizem suficientemente o esforço de nossa ambição. É isto o que aconselho hoje, dia da tua maioridade.

- Creia que lhe agradeço; mas que ofício, não me dirá?

- Nenhum me parece mais útil e cabido que o de medalhão. ${ }^{26}$

Acautelar um ofício para a hipótese de que os outros falhem? Ou que não venham a indenizar suficientemente o esforço de nossa ambição? Ora, Janjão, filho da restritíssima elite brasileira dos oitocentos, ${ }^{27}$ aprende com o pai que não é preciso ter verdadeira vinculação com o que se faz. O mote do trabalho não está no afinco da identificação com o que se faz, mas na prudência de possuir uma profissão junto à manga para o caso de o oportunismo não ser devidamente recompensado. Trata-se de se elevar, de caminhar sobre os ombros alheios, de ser notado sem que os demais notem o suor contra as têmporas. Não são a profundidade e a dedicação que caracterizam o fito do medalhão, mas a mera ambição. Por sinal, a finalidade se confunde com o prêmio, pois o medalhão sintetiza todos os auspícios com seu terno bem cortado e suas palavras geometricamente articuladas.

Podes empregar umas quantas figuras expressivas, a hidra de Lerna, por exemplo, a cabeça de Medusa, o tonel das Danaides, as asas de Ícaro, e outras, que românticos, clássicos e realistas empregam sem desar, quando precisam delas. Sentenças latinas, ditos históricos, versos célebres,

\footnotetext{
${ }^{26}$ Ibidem.

27 Em Os leitores de Machado de Assis, Hélio de Seixas Guimarães procura desvelar quem eram os leitores de Machado à época em que o escritor produzia sua obra - leitores da elite brasileira oitocentista que poderiam ter as mesmas aspirações de Janjão com vistas à teoria e à prática do medalhão. Conforme consta da orelha do livro: "Na passagem do século XIX para o XX, a população alfabetizada do Brasil correspondia a $18 \%$ do total, dos quais apenas $2 \%$ eram capazes de ler livros. [Sendo assim], a quem os narradores machadianos, em sua quase obsessão de diálogo com o leitor, se dirigiam é a questão que Hélio de Seixas Guimarães enfrenta neste livro. A figura do leitor na produção ficcional de Machado é o assunto central do estudo, buscando estabelecer conexões entre o diálogo com o leitor no plano ficcional e o embate histórico do escritor com seu público".
}

Machado de Assis Linha, São Paulo, v. 8, n. 15, p. 55-75, junho 2015

Universidade de São Paulo - Faculdade de Filosofia, Letras e Ciências Humanas 
brocardos jurídicos, máximas, é de bom aviso trazê-los contigo para os discursos de sobremesa, de felicitação, ou de agradecimento. ${ }^{28}$

Nesse momento, a suspeita de que a voz autoral se aproxima da prudência paterna traz um matiz algo outro para a análise. Machado já flertara com os românticos. $\mathrm{O}$ escritor, ilhado em um Brasil profundamente provinciano, percebia amplamente o uso decorativo e retrátil das figuras de estilo. Uso social, atavismo de uma distinção simbólica deformada pela periferia do capitalismo. A erudição equivale ao compêndio sempre à mão. Maquiavel, mencionado ao fim do diálogo, é interpretado à brasileira. A virtude, proveniente do vir, da virilidade, deve lançar mão dos mais diversos expedientes para copular com a irrequieta Fortuna, para seduzi-la, conquistá-la, dominá-la. À época, a erudição clássica, amplamente reificada, ainda era de bom tom. Hoje, a "Teoria do medalhão" original nos convida a pensar sobre o novo conteúdo histórico do medalhão, já que a burguesia contemporânea se despiu das vestes mais enfatuadas para sanear custos desnecessários. Se o tempo deve coincidir com a liquidez, os usos e costumes se encarregam de eliminar do discurso reificado as impurezas da inteligência que só fazem demonstrar pedantismo e afetação, uma vez que o vaivém das finanças já não precisa ser enaltecido por Virgílio.

Ao aproximarmos a voz paterna da voz autoral - afinal de contas, o autor não deixa de ser o pai do texto -, transmitimos a volubilidade narrativa para o próprio Machado de Assis. Seria possível definir inequivocamente as tendências políticas do escritor? E quanto à ironia machadiana que frequentemente turva a percepção retilínea do conteúdo? Machado e o pai de Janjão estariam, subrepticiamente, criticando o status quo? Seria possível ler a "Teoria do medalhão" como uma genealogia da moral burguesa no Brasil? Mas que dizer do sentido apologista que desponta como as medalhas na farda do alferes? Seria a disjunção a melhor alternativa de análise? Crítica ou apologia? Eis a síntese do diálogo entre James e Machado: crítica $e$ apologia.

Toda a questão é não infringir as regras e obrigações capitais. Podes pertencer a qualquer partido, liberal ou conservador, republicano ou ultramontano, com a cláusula única de não ligar nenhuma ideia especial a esses vocábulos. ${ }^{29}$

\footnotetext{
${ }^{28}$ ASSIS, cit., p. 291.

${ }^{29}$ Idem, p. 294.
} 
Crítica, é bem verdade, pois a elite brasileira, em seus redivivos acordos para a permanência no poder, bem sabe transformar a ex-colônia em uma monarquia independente, enquanto no restante da América Latina despontam repúblicas contra o antigo domínio colonial. Se quisermos insinuar a ironia de Machado de Assis em meio às artimanhas da elite brasileira, chegaremos a uma série de ruminações hipotéticas. Por que a elite brasileira oitocentista deveria nutrir quaisquer ressentimentos contra os antigos senhores coloniais? Portugal fora o pai do Brasil durante tantos séculos. Deixem, então, que o filho de Dom João VI governe o país, para que o poder se transforme e permaneça idêntico a si mesmo. Quando a abolição for inevitável, a elite fará dos antigos escravos os novos proletários. Não lhes serão pagas quaisquer indenizações, tais como desnecessários títulos de propriedade ou pequenas boladas em dinheiro; na verdade, os antigos escravos só farão reclamar da nova liberdade como um excesso de responsabilidade. Afinal - assim a elite sentencia -, ser escravo tem lá suas vantagens: cabe ao senhor o ônus de todas as decisões. A cláusula única de não ligar nenhuma ideia especial a correntes ideológicas fortemente contrárias - correntes que, no Brasil, eram reduzidas a meros vocábulos mostra o prisma pelo qual a elite brasileira consegue alijar o miseralato do poder social. Quando os acordos se dão apenas entre os pares, privatizam-se os ganhos, socializam-se as perdas.

Por outro lado - lado antípoda que emana da mesma volubilidade formal -, por que é que o respeito à cláusula única que apregoa a permutabilidade dos diferentes partidos não pode referir-se a uma receita de bem viver? Se Janjão seguir os conselhos do pai, o atual medalhão de cobre logo terá dezoito quilates. Uma leitura que aceite sem mais a apologia crítica do pai poderá entrever a vereda da vitória em meio ao vale de lágrimas. A maioria chora e range os dentes, mas os afortunados maquiavélicos, que aceitam incondicionalmente as regras do jogo e sabem vertê-las a favor de si mesmos, os astuciosos contumazes conseguem vestir a tão cobiçada pele de cordeiro, láurea-mor de um medalhão.

Somente não deves empregar a ironia, esse movimento ao canto da boca, cheio de mistérios, inventado por algum grego da decadência, contraído por Luciano, transmitido a Swift e Voltaire, feição própria dos céticos e desabusados. Não. Usa antes a chalaça, a nossa boa chalaça amiga, gorducha, redonda, franca, sem biocos, nem véus, que se mete pela casa dos 
outros, estala como uma palmada, faz pular o sangue nas veias, e arrebentar de riso os suspensórios. Usa a chalaça. ${ }^{30}$

Neste momento, a voz paterna, autoral e ficcional mostra a ambivalência da volubilidade formal para deformar ainda mais o conteúdo polissêmico. Ora, se o pai recomenda a Janjão que "não transcendas nunca os limites de uma invejável vulgaridade", 31 por que se preocupar em conhecer a genealogia da ironia? Por que ler Luciano de Samósata e seus diálogos que anteciparam formalmente a própria estrutura crítico-apologista da "Teoria do medalhão"? Por que dissecar cinicamente a trajetória de Cândido, de Voltaire, para saber que o melhor dos mundos possíveis, teoria-mor do Doutor Pangloss, não passa de uma filosofia de gabinete que não sobreviveria um único dia sem o mais contumaz tráfico de influências? Para que conhecer os solavancos narrativos de Swift, mestre inglês da ironia, que sempre deformava a estória escorreita com comentários dúbios e elípticos para a agonia do leitor mais tradicional e crédulo? Aqui, o pai de Janjão dá pistas sobre o porquê de não se ter tornado um medalhão: talvez ele não tenha sido hábil o bastante, mas certamente não aceitou condicionar o próprio intelecto à "inópia mental" que já entrevê no filho ouvinte. O pai demonstra verdadeira erudição e, assim, funde-se à voz autoral que ressoa e desvela os mecanismos de sucesso na opressão da sociedade. A ironia, estruturalmente volúvel, irredutível às múltiplas zombarias do pai, enforma o diálogo e gera a forma em meio à qual e por meio da qual a contradição pode movimentar a crítica e a apologia. Assim como o enigma insolúvel de James, a "Teoria do medalhão" movimenta-se com uma volubilidade formal que se adapta aos mais diversos conteúdos, fazendo com que os choques entre tese e antítese viabilizem o próprio curso narrativo, sem que haja uma síntese unívoca para o todo poético.

Talvez seja possível dizer que o autor, maestro da poética, paira sobre o vale de lágrimas ao manusear a batuta irônica que apregoa o existente ao denunciá-lo. Mas a altivez autoral não se sustenta pragmaticamente. A ironia abocanha a própria cauda, pois o autor irônico está sujeito às inflexões da mesma "Teoria do medalhão" a que dá forma volúvel e conteúdos díspares. No limite, a altivez do autor que pretende pairar sobre a miséria histórica

30 Ibidem.

${ }^{31}$ Ibidem. 
transforma-se em sadismo para o leitor que faz a apologia cúmplice e em masoquismo para o crítico que só faz ler o diálogo como crítica social. Ao fim e ao cabo, liberais e conservadores, republicanos e ultramontanos, querendo ou não, fazem coro a Quincas Borba. Ao vencedor, as batatas.

\subsection{O maquiavelismo da ironia de Machado de Assis: crítica e apologia}

Meia-noite? Entras nos teus vinte e dous anos, meu peralta; estás definitivamente maior. Vamos dormir, que é tarde. Rumina bem o que te disse, meu filho. Guardadas as proporções, a conversa desta noite vale o Príncipe de Machiavelli. Vamos dormir. $^{32}$

Diante da menção do pai de Janjão à obra-prima de Nicolau Maquiavel, será bastante propício para a nossa análise saber a quem o autor florentino dedicou $O$ Príncipe.

Ao magnífico Lorenzo, filho de Piero de Médicis. [...] Desejando eu oferecer a Vossa Magnificência um testemunho qualquer de minha obrigação, não achei entre os meus cabedais coisa que me seja mais cara ou que tanto estime quanto o conhecimento das ações dos grandes homens apreendido por uma longa experiência das coisas modernas e uma contínua lição das antigas, as quais, tendo eu, com grande diligência, longamente cogitado, examinando-as, agora mando a Vossa Magnificência, reduzidas a um pequeno volume. [...] Tome, pois, Vossa Magnificência, este pequeno presente com a intenção com que eu o mando. Se esta obra for diligentemente considerada e lida, Vossa Magnificência conhecerá o meu extremo desejo de que alcance aquela grandeza que a Fortuna e outras qualidades lhe prometem. E se Vossa Magnificência, do ápice da sua altura, alguma vez volver os olhos para baixo, saberá quão sem razão suporto uma grande e contínua má sorte. ${ }^{33}$

${ }^{32}$ Idem, p. 295.

${ }^{33}$ MAQUIAVEL, O Príncipe, p. 27-28.

Machado de Assis Linha, São Paulo, v. 8, n. 15, p. 55-75, junho 2015

Universidade de São Paulo - Faculdade de Filosofia, Letras e Ciências Humanas 
O Príncipe sempre foi interpretado pela fortuna crítica como uma pedagogia do poder destinada aos poderosos. Lições para a tomada e a manutenção do poder. Até que o socialista Antonio Gramsci, encarcerado por Benito Mussolini, torna polissêmico o maquiavelismo.

Segundo Gramsci, ${ }^{34} O$ Príncipe se curva diante dos poderosos para lhes ensinar a dinâmica do poder na mesma medida em que, ao ser impresso, passa a instruir os dominados sobre as práticas dos dominadores. Gramsci sugere, assim, que $O$ Príncipe, ainda que tenha sido dedicado ao pai e ao filho Médicis, constitui uma teoria impessoal da prática histórica do poder. Cabe aos dominados disputar a hegemonia com os dominantes para que a história deixe de ser desigual e arbitrária. Assim, se do ápice da sua altura, alguma vez os poderosos volverem os olhos para baixo, saberão quão sem razão os dominados suportam uma grande e contínua má sorte cuja genealogia, segundo Gramsci, foi traçada por Nicolau Maquiavel.

Podemos, assim, deduzir a leitura que Antonio Gramsci faria da "Teoria do medalhão". Não podemos ignorar, em todo caso, que $O$ Príncipe foi de fato dedicado "ao magnífico Lorenzo, filho de Piero de Médicis". Os poderosos não apenas se embriagaram com $O$ Príncipe como chegaram a demonstrar os limites da obra. Trago comigo uma versão do clássico maquiavélico comentada por ninguém mais que Napoleão Bonaparte. $\mathrm{O}$ imperialista francês dialoga com Maquiavel com a autoridade de quem prostrou a Europa sob os cascos de seu cavalo. Por outro lado - lado antípoda que emana da mesma volubilidade maquiavélica -, por que os dominados não poderiam aprender as práticas de tomada e manutenção do poder assim como o fez Maquiavel ao estudar as lições legadas pela história?

Mas, afinal, quem estaria com a razão: os apologistas ou os críticos? A reboque de seu mestre Arthur Schopenhauer, Machado de Assis talvez dissesse que "uma nação zomba da outra e todas têm razão". 35 "Teoria do medalhão": um longo aforismo para a sabedoria na vida. "A figura no tapete" a consideraria um enigma formal que consegue movimentar os contrários em seu transcurso narrativo. Um enigma volúvel e ambíguo, cuja forma dialógica não coincide consigo mesma. Ao fim e ao cabo, a sabedoria machadiana entrega a medalha

${ }^{34}$ GRAMSCI, Cadernos do cárcere, v. 1.

${ }^{35}$ SCHOPENHAUER, Aforismos para a sabedoria na vida, p. 74. 
para os vencedores, enquanto os vencidos, rangendo os dentes pela derrota, descascam as batatas para o purê dos patrões.

Apologia $e$ crítica, a depender da classe a que se pertence ou do ethos da classe que se defende. Com um movimento estrutural e contraditório análogo à poética da figura no tapete, "Teoria do medalhão" assumirá ora um conteúdo, ora outro, uma vez que sua forma irônica mimetiza a brutalidade da história que não chegou a uma síntese para a dialética entre o senhor e o escravo. A emancipação que não sobreveio confere atualidade ao conflito redivivo, cujo transcurso a ironia, motor da história, faz questão de explicitar e ocultar, denunciar e reproduzir.

\section{Referências}

ASSIS, Machado de. Teoria do medalhão. In: Obra completa. Rio de Janeiro: Nova Aguilar, 2004, v. 2, p. 288-295.

BEHIND the Name: The Etymology and History of First Names [Por detrás dos nomes: A etimologia $e$ a história dos nomes]. Disponível em: http://www.behindthename.com/name/hugh. Acesso em: 11 fev. 2015.

GRAMSCI, Antonio. Cadernos do cárcere. Tradução de Carlos Nelson Coutinho. Rio de Janeiro: Civilização Brasileira, 2007, v. 1.

GUIMARÃES, Hélio de Seixas. Os leitores de Machado de Assis: o romance machadiano e o público de literatura no século 19. 2. ed. São Paulo: Nankin/Edusp, 2012.

JAMES, Henry. A arte do romance: antologia de prefácios. Organização, tradução, notas e introdução de Marcelo Pen Parreira. São Paulo: Globo, 2003.

The figure in the carpet (E-book). New York: The Floating Press, 2011. [Ed. bras.: $\mathrm{O}$ desenho no tapete. In: A morte do leão: histórias de artistas e escritores. Tradução de Paulo Henriques Britto. São Paulo: Companhia das Letras, 1993, p. 144-180.]

KELLER, Alfred J. Dicionário Michaelis da língua alemã. São Paulo: Melhoramentos, 2002.

MAQUIAVEL, Nicolau. O Príncipe. Tradução de Pietro Nassetti. São Paulo: Martin Claret, 2002.

PARREIRA, Marcelo Pen. Realidade possível: dilemas da ficção em Henry James e Machado de Assis. São Paulo: Ateliê, 2012.

SANTO AGOSTINHO. Confissões. Tradução de J. Oliveira Santos. São Paulo: Nova Cultural, 1996.

SCHOPENHAUER, Arthur. Aforismos para a sabedoria na vida. Tradução de Oscar Arnaldo Meyer. São Paulo: Edições Melhoramentos, 1956. 
VILLAÇA, Alcides. “Janjão e Maquiavel: a Teoria do medalhão”. In: GRANJA, Lúcia; GUIDIN, Márcia Lígia; RICIERI, Francine Weiss (Orgs.). Machado de Assis: ensaios da crítica contemporânea. São Paulo: Editora Unesp, 2008.

WILDE, Oscar. Aforismos ou mensagens eternas. Tradução de Dênis Moreira de Carvalho. São Paulo: Landy, 2006.

FLÁVIO RICARDO VASSOLER é mestre e doutorando em Teoria Literária e Literatura Comparada pela FFLCH-USP. Atualmente, realiza um estágio doutoral, com financiamento pela CAPES, junto à Northwestern University, em Evanston, nos EUA. É autor das obras literárias Tiro de Misericórdia (nVersos, 2014) e O Evangelho segundo Talião (nVersos, 2013) e organizador do livro de ensaios Dostoiévski e Bergman: O niilismo da modernidade (Intermeios, 2012). E-mail: within_emdevir@yahoo.com.br. Bolsista da Capes - Proc. nº. 99999.004222/2014-08.

Recebido: 17.02.2015

Aprovado: 12.04.2015

Machado de Assis Linha, São Paulo, v. 8, n. 15, p. 55-75, junho 2015

Universidade de São Paulo - Faculdade de Filosofia, Letras e Ciências Humanas 